\title{
DIFFERENCES IN THE ELECTROPHORETIC CHARACTERISTICS OF BOVINE RETE TESTIS FLUID AND PLASMA FROM THE CAUDA EPIDIDYMIDIS
}

\author{
R. P. AMANN, G. J. KILLIAN AND A. W. BENTON \\ Dairy Breeding Research Center, Department of Dairy Science, and \\ Department of Entomology, The Pennsylvania State University, \\ University Park, Pa. 16802, U.S.A.
}

(Received 23rd October 1972)

\begin{abstract}
Summary. Polyacrylamide gel electrophoresis was used to evaluate rete testis fluid (RTF) and plasma from the cauda epididymidis (CEP) obtained from conscious Holstein bulls. The major protein in RTF had an electrophoretic mobility similar to that of blood serum albumin, but the seemingly analogous protein in CEP had a slower relative mobility. Bovine CEP contains at least three proteins, one glycoprotein and possibly three other PAS-positive components not detected in RTF or blood serum. In addition, esterases, acid phosphatases and several $\beta$-glucuronidases have been detected in CEP which were absent in RTF. Agarose immunoelectrophoretic analyses confirmed the basic differences among the three fluids. Although RTF and CEP share certain proteins with blood serum, each fluid is biologically unique. Certain proteins detected in CEP but not in RTF or blood serum probably originated from the testicular spermatozoa while others may represent epididymal secretion.
\end{abstract}

\section{INTRODUCTION}

The electrophoretic and antigenic characteristics of bovine seminal plasma, as well as those of other species, indicate differences from homologous blood serum (e.g. Wilson, 1969; Barker \& Amann, 1970). There are also distinct antigenic differences between plasma from the cauda epididymidis (CEP) and the seminal plasma of bulls (Barker \& Amann, 1970) and rams (Alumot, Lensky \& Schindler, 1971). This is not surprising since in 3-year-old Holstein bulls, the epididymides contribute only 19 to $31 \%$ of the ejaculate volume (Seidel \& Foote, 1970) and about half of this amount is spermatozoa (Crabo, 1965). Furthermore, the concentration of protein in CEP is lower than that in accessory sex gland fluids (30 versus $73 \mathrm{mg} / \mathrm{ml}$; Sexton, Amann \& Flipse, 1971). Thus, CEP contributes less than $10 \%$ of the protein found in the seminal plasma. Antigens found in CEP but absent from accessory sex gland fluid or blood serum do not necessarily represent epididymal secretion since some proteins are contributed in rete testis fluid (RTF) while other components apparently are of sperm origin (Barker \& Amann, 1970, 1971; Killian \& Amann, 1973). 
The objective of this study using electrophoretic analyses was to determine if GEP contained proteins not detectable in blood serum or RTF.

\section{MATERIALS AND METHODS}

Reproductive fluids and blood serum were obtained from conscious, unrestrained 2- to 11-year-old Holstein bulls (Table 1). When all three fluids were analysed for a single bull, the samples were not always taken at the same time. The RTF was collected from six bulls through a Silastic cannula (Amann, Kavanaugh \& Griel, 1970; Sexton et al., 1971) and from two bulls through a silicone rubber catheter (Voglmayr, Kavanaugh, Griel \& Amann, 1972). Samples from Bulls 289, 290 and 294 represented a 12- to 24-hr accumulation at ambient barn temperature during autumn or winter months while samples from Bulls 357 and 359 represented a 30- to 60 -min accumulation during June.

Table 1. Sources of fluids analysed

\begin{tabular}{c|c|c|c}
\hline \multirow{2}{*}{$\begin{array}{c}\text { Bull } \\
\text { no. }\end{array}$} & \multicolumn{3}{|c}{ No. of samples } \\
\cline { 2 - 4 } & $\begin{array}{c}\text { Rete } \\
\text { testis }\end{array}$ & $\begin{array}{c}\text { Cauda } \\
\text { epididymidis }\end{array}$ & $\begin{array}{c}\text { Blood } \\
\text { serum }\end{array}$ \\
\hline 289 & 4 & - & - \\
290 & 3 & - & - \\
294 & 9 & - & - \\
356 & - & $1^{*}$ & 1 \\
357 & 5 & $1^{*}$ & -1 \\
358 & -5 & 5 & 2 \\
359 & - & - & 1 \\
340 & - & & \\
\hline
\end{tabular}

* Each sample represents a pool of two collections, 24 hr apart.

Samples of RTF were taken between $4 \mathrm{hr}$ and 12 days after surgery while the rate of flow and concentration of spermatozoa appeared normal. Traces of haemoglobin were present in three samples. The RTF was separated from the spermatozoa by centrifugation and then clarified (1000 $\mathrm{g}$ for $7 \mathrm{~min}$ and $3000 \mathrm{~g}$ for $10 \mathrm{~min}$ for samples from three bulls; $350 \mathrm{~g}$ and $20,000 \mathrm{~g}$ for $10 \mathrm{~min}$ for samples from two bulls) before storage below $-20^{\circ} \mathrm{C}$.

Spermatozoa and CEP were obtained during May and June through a cannula placed in the proximal ductus deferens (Sexton et al., 1971). Except for the 10 to 20 min required each day for sample collection, the ductus deferens cannula was occluded with a small clamp. Samples were obtained 3 to 12 days after surgery by allowing the bull to mount a 'teaser' three times (false mounts) followed by a fourth mount and ejaculation into an artificial vagina. With each mount, fluid was forced through the cannula in the ductus deferens. The void volume of the cannula was small (about $0.08 \mathrm{ml}$ ) and the first few drops were discarded. The fluid and spermatozoa collected were taken to represent those found in the distal cauda epididymidis. Following collection, a sample was diluted with four vols of phosphate-buffered saline ( $\mathrm{pH} \mathrm{7.4)} \mathrm{or}$ occasionally tris- $\mathrm{HCl}$ buffer $(\mathrm{pH} \mathrm{7.4}$ ) and centrifuged at $350 \mathrm{~g}$ for $10 \mathrm{~min}$. 
The supernatant, dilute GEP, was clarified $(20,000 \mathrm{~g}$ for $10 \mathrm{~min})$ and stored at $-196^{\circ} \mathrm{C}$.

Blood serum was prepared by centrifuging (1000 $\mathrm{g}$ for $15 \mathrm{~min})$ clotted peripheral blood and the serum was then recentrifuged at 20,000 $\mathrm{g}$ and stored below $-20^{\circ} \mathrm{C}$. Individual samples from four bulls were analysed.

Electrophoretic analyses utilized a $7 \%$ polyacrylamide gel with a trisglycine buffer ( $\mathrm{pH} 9.5$ ) and bromphenol blue as the tracking dye (Benton \& Myers, 1967). Generally, $60 \mu \mathrm{l} \mathrm{RTF} \mathrm{(without} \mathrm{concentration),} 30 \mu \mathrm{l}$ of the $1: 4$ diluted CEP or $3 \mu \mathrm{l}$ blood serum were applied to a gel. Following separation at $5 \pm 3^{\circ} \mathrm{C}$, components in the gels were stained with amido black followed by electric destaining. Alternatively, gels were stained with the PAS-technique using $10 \%$ acetic acid for destaining. The location of each band was measured in four duplicate gels per sample stained by each method and the mean relative mobilities $\left(\mathbf{M}_{\mathbf{x}}\right)$ of protein and PAS-positive components were calculated. No difference was obvious in the electrophoretic pattern of CEP diluted with tris or phosphate buffers or for RTF centrifuged at different gravitational forces. The data were therefore pooled. Conclusions that components in the three fluids had differing relative mobilities $(P<0.01)$ or that a component was a glycoprotein (non-significant difference between relative mobilities of protein and PAS-positive components) were based on analyses of variance and use of a modified Duncan's LSD test (Waller \& Duncan, 1969). Estimates of the relative concentrations of amido black-stained proteins were based on densitometric analysis of two gels for each sample. A Photovolt system incorporating a 420-nm filter and an integrator unit was used.

Gels representing two samples of each fluid were sectioned longitudinally and one half of each was stained for protein. The other halves were stained by the PAS-technique for $\alpha$-naphthol esterase activity (Benton \& Myers, 1967) or for acid phosphatases using sodium naphthol AS-TR phosphate, $\mathcal{N}$-acetyl- $\beta$-Dglucosamine naphthol AS-LC, and naphthol AS-BI $\beta$-D-glucuronic acid as substrates in reactions utilizing hexazonium pararosaniline as the simultaneous diazo coupler (Barka \& Anderson, 1962; Hayashi, Nakajima \& Fishman, 1964; Hayashi, 1965).

To facilitate identification of components in CEP which were not present in either RTF or blood serum, three samples of CEP were fractionated by preparative polyacrylamide gel electrophoresis using a Buchler Poly-Prep 100. Each sample fractionated contained 60 to $70 \mathrm{mg}$ protein and the conditions of electrophoresis were similar to those described above. Each 10-ml fraction of eluate was evaluated by analytical gel electrophoresis, as described above, and fractions containing single protein bands were concentrated using Sephadex G-25 and then subjected to immunoelectrophoresis.

Antisera were produced in rabbits against blood serum, CEP, RTF, and testicular spermatozoa. Globulins were separated and utilized, before or after absorption with blood serum, for microimmunoelectrophoretic analyses (Killian \& Amann, 1973).

\section{RESULTS}

The interval after surgery was not associated with any consistent change in 
protein composition of RTF. Data for one series of samples (Text-fig. 1) show that typically there was a major component with an electrophoretic mobility similar to that of serum albumin $\left(\mathbf{M}_{\mathrm{x}} \simeq 0.82\right)$ and probably three partially separated components with mean relative mobilities of $0.41,0.44$ and 0.48 . The apparent shift in mobilities for the sample on 15th June may be an artifact. The relative amounts of components with mobilities less than 0.26 differed among samples from each bull. For the three samples from Bull 294 with visually detectable blood contamination, the electrophoretograms were similar to those shown in Text-fig. 1. Not all protein in the sample entered the separating geI with this anodic system. Of the material which did enter the gels, for the

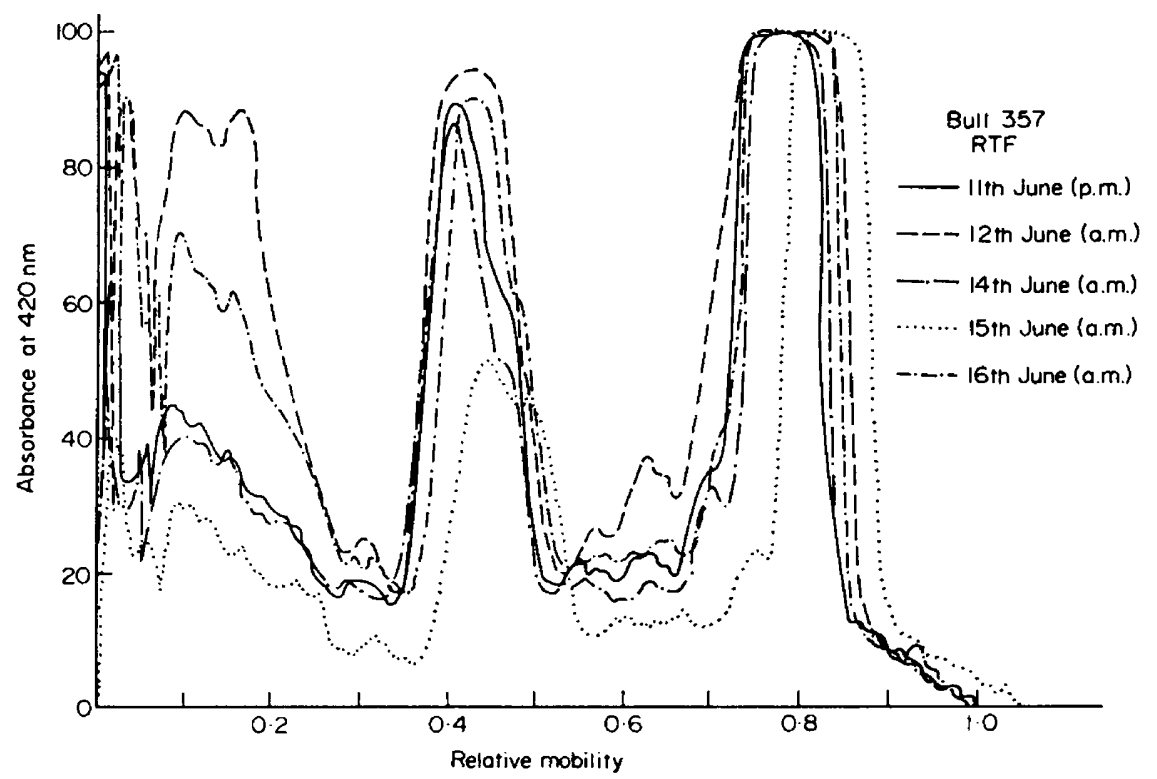

Text-fig. 1. Densitometric tracings of amido black-stained proteins in electrophoretograms representing samples of RTF collected from one bull at five different intervals after cannulation of the rete testis. The sample of $1 \mathrm{lth}$ June was collected about $4 \mathrm{hr}$ after cannulation and a 'normal' flow of R'TF was obtained until 18th June 1971. (The cannula remained patent until 28 th June 1971.)

twenty-six samples analysed, $69 \%$ of the protein was estimated to have a relative mobility greater than $0 \cdot 26$.

Despite differences among samples of RTF from the same or different bulls (Text-figs 1 and 2), there was an obvious pattern in all electrophoretograms. Considering all samples of RTF, a total of thirty-one bands was detected and these subsequently were grouped into twenty-one bands, each with a different $(P<0.01)$ relative mobility (Text-fig. 3). For individual samples of RTF, however, only seven to fourteen bands (with $M_{x}>0 \cdot 10$ ) were sufficiently intense to allow measurements of mobility. No consistent difference in RTF associated with bulls or the interval after surgery was apparent.

The electrophoretic patterns for CEP are summarized and compared with 


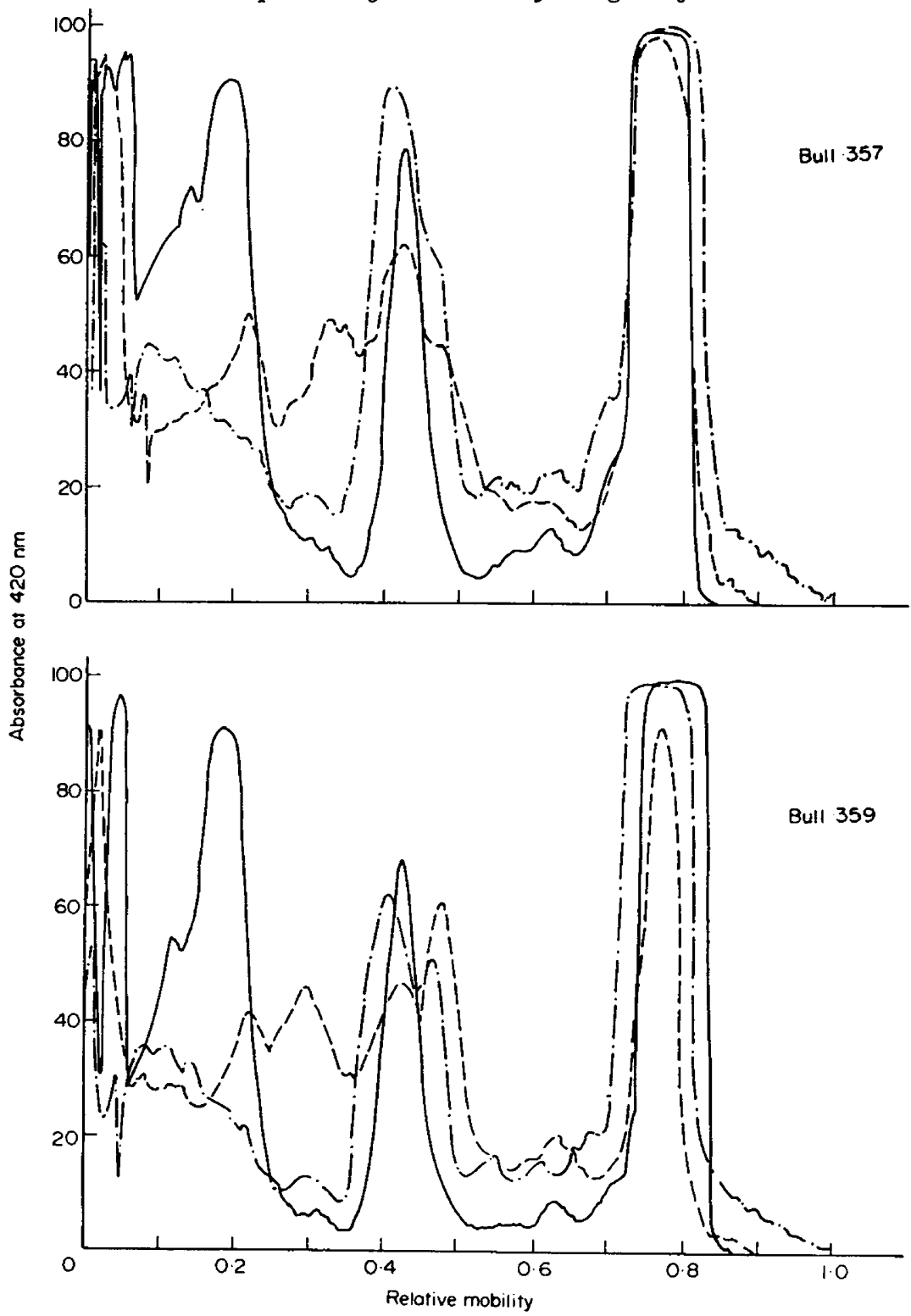

Text-FIG. 2. Densitometric tracings comparing the amido black-stained proteins in electrophoretograms of bull RTF $(-,-)$, CEP $(---)$ and blood serum (- - . Prealbumins in RTF and CEP with a relative mobility greater than 1.0 are not shown. Cannulations in Bull 357 were made on 11 th June 1971 and the sample dates were 11 th June for RTF, 18th June for GEP and 7th July for serum. For Bull 359, cannulations were made on 8 th June 1971 and the sample dates were 12 th June for RTF, 18th June for CEP and 7th July for serum.

those for RTF and blood serum in Text-figs 2 and 3. The electrophoretograms depicted for Bulls 357 and 359 are typical of all samples of their RTF and CEP. The CEP contained a major component with a mean electrophoretic mobility of 0.78 which was different $(P<0.01)$ from that of serum albumin, 


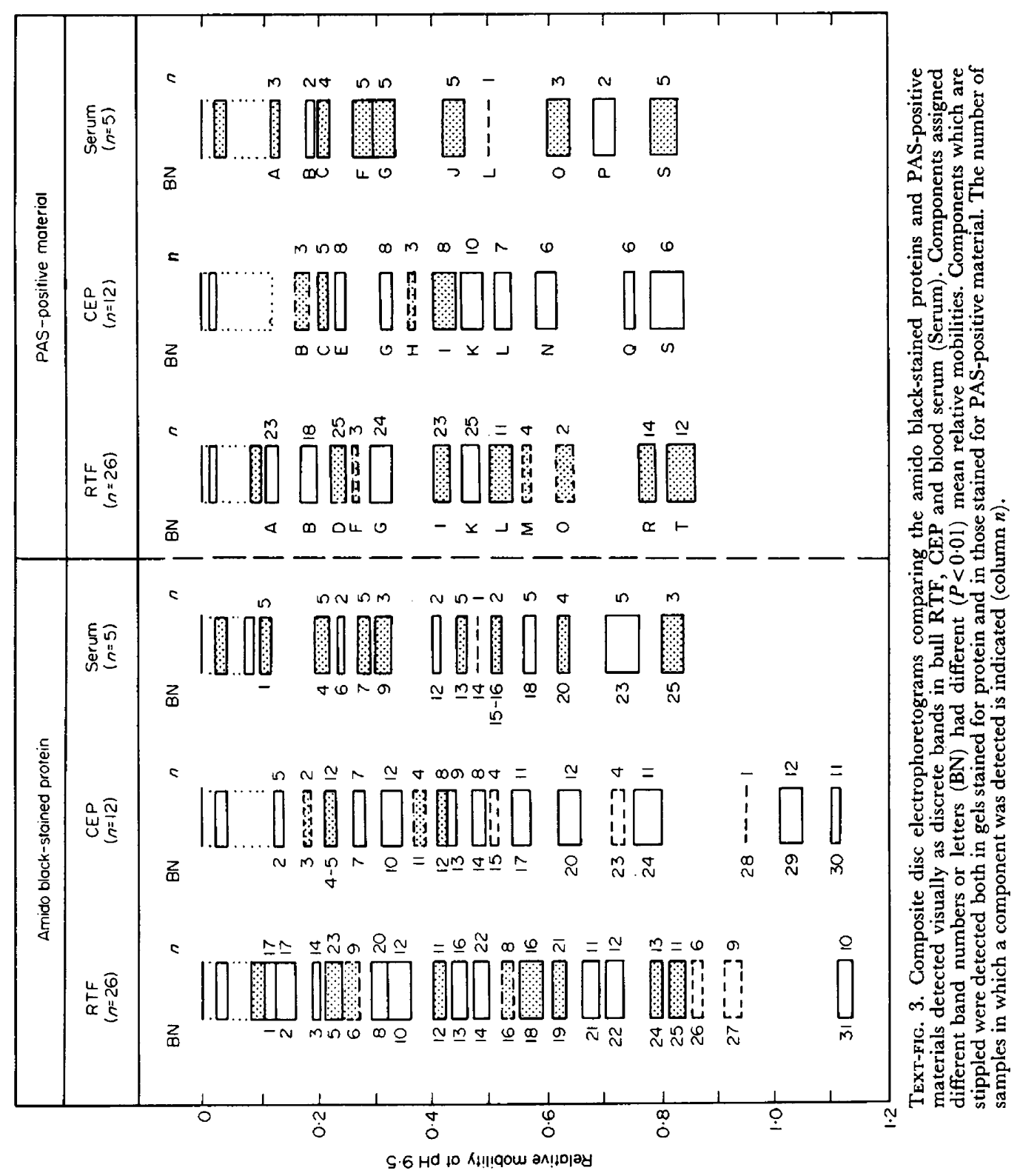


but not significantly different from that of a major component(s) detected in thirteen out of twenty-six samples of R'TF (Band 24, Text-fig. 3). The relative mobility of this albumin-like component in CEP was consistently between 0.75 and 0.81 while in RTF, it was between 0.75 and 0.87 ; in the latter fluid, values for this component(s) fell into two groups (Bands 24 and 25). For four of twentysix samples of RTF, both components in this broad band were detected individually. This fact, and the fact that variation in relative mobility was recorded for all samples, suggests that RTF may contain several components with relative mobilities averaging $0 \cdot 78,0.82$ and 0.86 .

One component (Band 18 ) in RTF had a relative mobility identical to that of one of the bands (18 and 20) presumed to represent $\alpha$-globulins in blood serum. A similar component (Band 20, $\mathrm{M}_{\mathbf{x}}=0.64$ ) was detected in CEP. Immunological analyses of fractionated CEP, however, indicated that the component with a mean relative mobility of 0.64 was not detectable with globulin against bovine blood serum, although it was clearly detected as a single arc using globulin against CEP or the same globulin absorbed with blood serum. Apparently Band 20 in GEP is immunologically different from the band with a similar relative mobility in blood serum.

Both disc electrophoresis of CEP and immunoelectrophoretic analysis of the fraction with a relative mobility of 0.57 suggest that the component in Band 17 is not found in either blood serum or RTF.

All three fluids contained components, presumed to be $\beta$-globulins, with relative mobilities of approximately $0.41,0.44$ and 0.48 . Although only Band 13 was detected consistently in blood serum, most samples of RTF contained the two faster migrating bands (13 and 14) while about half of the samples of RTF contained Band 12 in combination with either Band 13 or 14 . For most samples of CEP, two or three bands with relative mobilities between 0.40 and 0.49 were recorded. Since Band 12 and especially Band 14 were frequently detected in RTF and GEP, but rarely and only in trace amounts in blood serum (Text-figs 1 to 3), components represented by Bands 12,13 and 14 are probably carried from the testis into the epididymis by RTF. Alternatively, they might pass into both fluids directly from the blood. Although Band 13 was found in all three fluids, different components may be involved. This band was detected by PAS-staining only in serum. Furthermore, a component with a relative mobility of 0.43 which was isolated from GEP was detectable by immunoelectrophoresis using globulin against CEP (with or without absorption with blood serum) but not with globulins against blood serum or RTF absorbed with blood serum. If this fraction represents Band 13 in CEP, it probably is not of blood or RTF origin.

Invariably, CEP contained component(s) with a relative mobility of $0 \cdot 33$. No component similar to Band 10 was detected in blood serum but, in twelve of twenty-six samples of RTF, traces of a component with a similar mobility $\left(M_{x}=0.34\right)$ were detected. As indicated in Text-fig. 3, CEP also contained the similarly migrating PAS-positive component G. Statistical analysis, however, indicated that the relative mobility of this component was less than that of the protein Band 10 in CEP. Relatively high concentrations of slower components $\left(\mathrm{M}_{\mathrm{x}}=0.27\right.$ to 0.38$)$ distinguished CEP from both RTF and blood 
serum (Text-fig. 2). In addition, the relatively low concentrations of components with electrophoretic mobilities between 0.12 and 0.24 in RTF and CEP, as compared to those in bovine serum (Text-fig. 2), suggest that the samples analysed in this study were not grossly contaminated with blood serum.

Following electrophoresis of RTF, only three esterase isozymes were detected. No positive histochemical reaction for acid phosphatases was obtained with RTF. By contrast, CEP contained a number of enzymes present in sufficient concentration for their detection. In addition to at least one esterase not detected in RTF, the CEP contained two prominent and three or four weak bands with $\beta$-glucuronidase activity and a diffuse band of $\mathcal{N}$-acetylglucosaminidase.

\section{DISCUSSION}

These analyses showed that CEP and RTF each contain unique and characteristic components in addition to those common to both fluids and blood serum. Our data support and amplify earlier reports that RTF from the ram (Johnson \& Setchell, 1968) and rat (Koskimies, Kormano \& Hunter, 1971) contain certain blood proteins. Based on data for rats (Koskimies, Kormano \& Lahti, 1971 ; Koskimies, Kormano \& Hunter, 1971), it seems probable that most of the blood proteins found in RTF of bulls (Text-fig. 3; Killian \& Amann, 1973) and rams (Johnson \& Setchell, 1968; Edwards, 1969) are added to this fluid in the rete testis and do not represent part of the primary secretion of the seminiferous tubules. Other components, such as those in Bands 5, 8, 21, 22 and 31 (Text-fig. 3), may arise in the seminiferous tubules.

The electrophoretic pattern of ram RTF separated on cellulose acetate (Johnson \& Setchell, 1968) is grossly similar to that reported herein for the bovine fluid. However, the better separations characteristic of the disc-gel technique resolved a number of minor bands not previously reported for RTF. In addition to an albumin band, Johnson \& Setchell (1968) found only a single, broad peak whose major component(s) migrated at a rate similar to the $\alpha$-globulins of ovine blood serum but which also contained several slower moving components.

It is clear that the passage of blood proteins into $\mathrm{RTF}$ is rather selective for both rams and bulls and not the result of a simple filtration process. Although proteins in R'TF are concentrated in the caput epididymidis (Crabo, 1965), the RTF may not serve as the sole source of blood proteins detectable in CEP. Both the present data and immunological studies (Killian \& Amann, 1973) support the conclusion that, at least quantitatively, the mixture of blood proteins in GEP is very different from that in RTF. A portion of the blood proteins in CEP of bulls (Barker \& Amann, 1971; Killian \& Amann, 1973), rams (Alumot, Lensky \& Schindler, 1971) and boars (Schellpfeffer \& Hunter, 1970; Dostál \& Veselský, 1972) may enter the lumen of the ductus epididymidis from the periductular vascular plexus. However, it was calculated (R. P. Amann, unpublished observation) that about $100 \mathrm{mg}$ protein enters the bovine caput epididymidis daily in RTF while only about $12 \mathrm{mg} /$ day is recovered in CEP. Clearly, the twentyfold increase in protein concentration is accompanied 
by a net loss of protein from the fluid in the epididymis. Thus, selective concentration of some proteins concurrent with this general resorption of proteins could account for many of the differences detected between RTF and CEP.

The electrophoretic pattern of CEP has been reported for rams (Alumot et al., 1971) and boars (Einarsson, Crabo \& Ekman, 1970; Lavon \& Boursnell, 1971). The broad spectrum of proteins detected in bovine CEP was thus expected. Some of the non-blood proteins in CEP may have originated in RTF. For example, the proteins identified as Bands 10 and 13 (Text-fig. 3) appear to have been contributed to CEP in the RTF. Certain other proteins (e.g., Band 20) in CEP were electrophoretically, biochemically or immunologically distinct from proteins detected in RTF or blood serum. Thus, some components must be of epididymal or sperm origin. As reported for boars (Einarsson et al., 1970 ), the relative mobility of the major albumin in bull CEP was slightly less $(P<0.01)$ than that of serum albumin $\left(M_{x}\right.$ of 0.78 versus 0.82$)$. Furthermore, the albumin in CEP was not PAS-positive as were the albumins in RTF and blood serum. Immunoelectrophoretic analyses, however, revealed that all of these albumins formed precipitin arcs with monospecific anti-bovine serum albumin.

Bovine CEP contained a greater diversity of esterases and substrate-specific acid phosphatases than RTF. It seems likely that some of the enzymes and isozymes found in CEP may be released from the cytoplasmic droplet (Dott \& Dingle, 1968; Garbers, Wakabayashi \& Reed, 1970; Moniem \& Glover, 1972) of spermatozoa during epididymal transit, but their exact source may be hard to establish. Ram RTF contains many enzymes (Suominen \& Setchell, 1972) and sites of acid phosphatase activity are common in the epididymal epithelium of rats (Pugh \& Walker, 1961; Hayashi, 1967; Martan, 1969; Snaith \& Levvy, 1969) and bulls (R. P. Amann, unpublished observation). Immunological analyses (Killian \& Amann, 1973) revealed that portions of the spermatozoa other than the cytoplasmic droplet also contribute to the protein found in CEP.

\section{ACKNOWLEDGMEN'TS}

This research was authorized for publication as Paper No. 4316 in the journal series of the Pennsylvania Agricultural Experiment Station, and was conducted pursuant to Contract NIH-NICHD 69-2137 and supported in part by Grant HD-01356. Appreciation is expressed to Dr J. F. Kavanaugh, Dr J. K. Voglmayr and Dr L. C. Griel, Jr for performing surgery and to Mrs Lois Yorty for skilled technical assistance.

\section{REFERENGES}

Alumot, E., Lensky, Y. \& Schindler, H. (1971) Separation of proteins in the epididymal fluid of the ram. J. Reprod. Fert. 25, 349.

Amann, R. P., Kavanaugh, J. F. \& Griel, L. C., JR (1970) Cannulation of bull rete testis and vas deferens. J. Anim. Sci. 31, 216.

Barka, T. \& Anderson, P. J. (1962) Histochemical methods for acid phosphatase using hexazonium pararosaniline as coupler. F. Histochem. Cytochem. 10, 741.

Barker, L. D. S. \& Amann, R. P. (1970) Epididymal physiology. I. Specificity of antisera against bull spermatozoa and reproductive fluids. 7. Reprod. Fert. 22, 441. 
Barker, L. D. S. \& Amann, R. P. (1971) Epididymal physiology. II. Immunofluorescent analyses of epithelial secretion and absorption, and of bovine sperm maturation. 7 . Reprod. Fert. 26, 319.

Benton, A. W. \& Myers, R. F. (1967) Esterases, phosphatases, and protein patterns of Ditylenchus triformis and Panagrellus redivivus. Nematologica, 12, 495.

Grabo, B. (1965) Studies on the composition of epididymal content in bulls and boars. Acta vet. scand. 6, Suppl. 5.

DostÁl, J. \& VeselskÝ, L. (1972) Proteins in the seminal plasma and the accessory sexual gland fluids of the boar. 7 . Reprod. Fert. 30, 255.

DotT, H. M. \& Dingle, J. T. (1968) Distribution of lysosomal enzymes in the spermatozoa and cytoplasmic droplets of bull and ram. Expl Cell Res. 52, 523.

EDWARDs, R. G. (1969) Antigenicity of spermatozoa with respect to fertility and infertility. In: Proc. Ist Int. Symp. Immunol. Sperm. and Fert., Varna, p. 27.

Einarsson, S., Grabo, B. \& Ekman, L. (1970) A comparative study of the chemical composition of plasma from the cauda epididymidis, semen fractions, and whole semen in boars. Acta vet. scand. 11, 156.

Garbers, D. L., Wakabayashi, T. \& Reed, P. W. (1970) Enzyme profile of the cytoplasmic droplet from bovine epididymal spermatozoa. Biol. Reprod. 3, 327.

Hayashi, M. (1965) Histochemical demonstration of $\mathcal{N}$-acetyl- $\beta$-glucosaminidase employing naphthol AS-BI $\mathcal{N}$-acetyl- $\beta$-glucosaminide as substrate. $\mathcal{F}$. Histochem. Cytochem. 13, 355.

Hayashi, M. (1967) Comparative histochemical localization of lysosomal enzymes in rat tissues. $\mathcal{F}$. Histochem. Cytochem. 15, 83.

Hayashi, M., Nakajima, Y. \& Fishman, W. H. (1964) The cytologic demonstration of $\beta$-glucuronidase employing naphthol AS-BI glucuronide and hexazonium pararosanilin; a preliminary report. 7. Histochem. Cytochem. 12, 293.

Johnson, M. H. \& Setchell, B. P. (1968) Protein and immunoglobulin content of rete testis fluid of rams. 7. Reprod. Fert. 17, 403.

Killian, G. J. \& Amann, R. P. (1973) Immunoelectrophoretic characterization of fluid and sperm entering and leaving the bovine epididymis. Biol. Reprod. (in press).

Koskimies, A. I., Kormano, M. \& Hunter, R. L. (1971) Combination of micropuncture and high resolution electrophoretic techniques for the study of rat testicular fluid proteins. Scand. $\mathcal{J}$. clin. Lab. Invest. 27, Suppl. 116, 6.

Koskimies, A. I., Kormano, M. \& Lahti, A. (1971) A difference in the immunoglobulin content of seminiferous tubule fluid and rete testis fluid of the rat. $\mathcal{J}$. Reprod. Fert. 27, 463.

Lavon, U. \& Boursnell, J. C. (1971) Gharacterization of boar seminal plasma, vesicular secretion and epididymal plasma proteins by gel disc electrophoresis and isoelectric focusing on polyacrylamide. 7. Reprod. Fert. 27, 227.

Martan, J. (1969) Epididymal histochemistry and physiology. Biol. Reprod. 1, Suppl. 1, 134.

Moniem, A. \& Glover, T. D. (1972) Alkaline phosphatase in the cytoplasmic droplet of mammalian spermatozoa. 7. Reprod. Fert. 29, 65.

Pugh, D. \& Walker, P. G. (1961) The localization of $\mathcal{N}$-acetyl- $\beta$-glucosaminidase in tissues. $\mathcal{F}$. Histochem. Cytochem. 9, 242.

Schellpfeffer, D. A. \& Hunter, A. G. (1970) Electrophoretic and gel filtration behaviour of boar seminal plasma proteins before and after removal of accessory sex glands. J. Reprod. Fert. 23, 291.

Seidel, G. E., JR \& Foote, R. H. (1970) Compartmental analysis of sources of the bovine ejaculate. Biol. Reprod. 2, 189.

Sexton, T. J., Amann, R. P. \& Flipse, R. J. (1971) Free amino acids and protein in rete testis fluid, vas deferens plasma, accessory sex gland fluid, and seminal plasma of the conscious bull. $\mathcal{J}$. Dairy Sci. 54, 412.

SNatth, S. M. \& Levvy, G. A. (1969) Purification and properties of $\alpha$-D-mannosidase from rat epididymis. Biochem. 7. 114, 25.

Suominen, J. \& Setchell, B. P. (1972) Enzymes and trypsin inhibitor in the rete testis fluid of rams and boars. 7. Reprod. Fert. 30, 235.

Voglmayr, J. K., Kavanaugh, J. F., Griel, L. G., Jr \& Amann, R. P. (1972) A modified technique for cannulating the rete testis of the bull. 7. Reprod. Fert. 31, 291.

Waller, R. A. \& Duncan, D. B. (1969) A Bayes rule for the symmetric multiple comparisons problem. 7. Am. statist. Ass. 64, 1484.

WILson, E. M. (1969) Some physico-chemical, immunological and electrophoretic properties of bovine seminal plasma and their implications in the reproductive process. Ph.D. thesis, Ohio State University, Columbus. 